\title{
Ткаченко В. В.
}

молодший науковий співробітник сектору дошкільної, загальної середньої і позашкільної освіти відділу освітньої статистики і аналітики ДНУ «Інститут освітньої аналітики», Київ, Україна, v.tkachenko@iea.gov.ua ORCID ID: https://orcid.org/0000-0002-3389-9935

\section{Дронь Т. 0.}

молодший науковий співробітник сектору вищої освіти відділу освітньої статистики і аналітики ДНУ «Інститут освітньої аналітики», Київ, Україна, t.dron@iea.gov.ua ORCID ID: https://orcid.org/0000-0003-1374-5610

\section{ІННОВАЦІЙНІ ПІДХОДИ ДО ОРГАНІЗАЦІЇ ОСВІТНЬОГО ПРОЦЕСУ В ПОЧАТКОВІЙ ШКОЛІ В КОНТЕКСТІ НУШ}

\begin{abstract}
Анотація. У статті розглянуто інноваційні підходи до організації освітнього процесу в початковій школі в контексті запровадження концепції Нової української школи (НУШ), їх роль у розвитку дитини як особистості, важливість трансформації освітнього процесу в умовах упровадження реформи. Серед ключових аспектів початкової освіти розглянуто ідеологію дитиноцентризму як основу особистісно орієнтованої моделі освіти, у межах якої в організації освітнього процесу максимально повинні враховуватися права кожної дитини, її здібності, а також потреби й інтереси. У матеріалі також було проаналізовано оновлену структуру освітнього процесу в початковій школі, зокрема ії розподіл на два цикли навчання: адаптаційно-ігровий і основний, що $\epsilon$ одним із шляхів реалізації особистісно орієнтованої моделі навчання. Такий розподіл передбачає врахування вікових особливостей психобізіологічного, пізнавального розвитку та потреб учнів. У контексті НУШ важливої ролі набуває організація освітнього середовища, яке має бути творчим та забезпечувати використання різних форм роботи, сприяти розвитку в учнів стійкого пізнавального інтересу; його створення це спільна діяльність усіх учасників освітнього процесу. Також наведено результати досліджень щодо ключових аспектів реформи НУШ.
\end{abstract}

Ключові слова: дитиноцентризм, інновації, компетентності, концепція, нова українська школа, освітній процес, особистість, підходи, початкова освіта, цінності.

JEL classification: A13.

DOI: $10.32987 / 2617-8532-2021-2-117-127$.

Кардинальні реформації, що масштабно відбуваються в системі освіти України, починаючи 3 2018 року, спрямовані на трансформацію української школи на важіль соціальної рівності й згуртованості, економічного розвитку й конкурентоспроможності держави [1]. Перехід від школи переважно теоретичних (C) Ткаченко В. В., Дронь Т. О., 2021 знань до школи компетентностей, необхідних особистості для успішної самореалізації, а також формування цінностей, які допоможуть у дорослому житті обрати професію, знайти своє покликання й реалізувати свій творчий потенціал, стати гідним громадянином, сім'янином тощо - основні підвалини реформи загальної 
середньої освіти. У реформу Нової української школи закладено важливу соціальну місію - стати провідником педагогічних, соціальних і соціокультурних інновацій, бастіоном високих моральних і соціальних традицій [2]. Методологічними й нормативними основами реформування освіти є закони України «Про освіту», «Про повну загальну середню освіту», Концепція «Нова українська школа», Державний стандарт початкової освіти. Нині реформа активно впроваджується на рівні початкової освіти - першого рівня повної загальної середньої освіти.

Основні засади реформування початкової освіти сформульовано в працях вітчизняних учених, таких як О. Я. Савченко, Н. М. Бібік, В. О. Мартиненко, К. І. Пономарьова, О. В. Онопрієнко, Н. З. Софій, О. І. Ляшенко та ін.

За визначенням О. В. Онопрієнко, місія початкової освіти полягає в плеканні особистості дитини, що досягається зокрема організацією освітнього процесу відповідно до іiі вікових й індивідуальних психофізіологічних особливостей, і спрямовано на формування в неї як загальнокультурних і морально-етичних цінностей, так і ключових, і предметних компетентностей, а також життєвих і соціальних навичок, що покликані забезпечити її готовність до продовження навчання в майбутньому. Iншими словами, в особистісному вимірі результатом початкової освіти $\epsilon$ дитина, яка вмотивована на успішне навчання, має дослідницьке ставлення до життя, володіє навичками отримання навчального досвіду 3 різних джерел, при цьому критично оцінює одержану інформацію, відповідально ставиться як до себе, так і до інших, усвідомлює себе громадянином/громадянкою України [3].

O. I. Ляшенко зазначає, що освітній процес у закладі освіти повинен грунтуватися на запровадженні компетентнісно орієнтованих методик і технологій навчання й оцінювання результатів навчання, варіативності форм і методів навчання учнів, що враховуватимуть вікові й пізнавальні особливості дітей і їхні здібності, а також інтереси й освітні потреби [4].

0. Я. Савченко зауважує, що базовими теоретичними положеннями конструювання змісту початкової освіти $є$ реалізація принципу дитиноцентризму в усіх його вимірах і діяльнісного підходу [5].

Мета статті полягає в огляді інноваційних підходів до організації освітнього процесу в початковій школі в умовах упровадження Концепції «Нової української школи» (далі НУШ) з акцентуацією на особистісно орієнтованій моделі освіти, що грунтується на принципах дитиноцентризму; формуванні загальнолюдських цінностей; структурі освітнього процесу й організації освітнього середовища.

Відповідно до Закону України «Про освіту» освітній процес визначається як система науково-методичних і педагогічних заходів, спрямованих на розвиток особистості шляхом формування та застосування іï компетентностей [6]. У Законі України «Про повну загальну середню освіту» закріплено, що освітній процес повинен бути передусім спрямованим на виявлення та розвиток здібностей й обдарувань особистості, їі індивідуальних здібностей, досягнення результатів навчання, прогресу в розвитку, зокрема формування 
і застосування відповідних компетентностей, визначених державними стандартами [7].

Таким чином, у НУШ упроваджується особистісно орієнтована модель освіти, у межах якої в організації освітнього процесу максимально повинні враховуватися права кожної дитини, іï здібності, а також потреби й інтереси. Призначення особистісно орієнтованої моделі освіти у підсумку полягає в розширенні можливостей кожної дитини зробити усвідомлений вибір свого життєвого шляху, самостійно спланувати власний розвиток для самореалізації в майбутньому. Основою цієї моделі освіти $є$ ідеологія дитиноцентризму, суть якої полягає в персоналізації освітнього процесу, свободі вибору власної освітньої траєкторії, урахуванні цінностей та інтересів дитини для формування в неї основ життєвої компетентності [8].

Зупинимося більш детально на принципі дитиноцентризму. Ідеї дитиноцентризму, актуальні для НУШ, були сформульовані й узагальнені В. Г. Кременем. Відповідно практична реалізація дитиноцентризму полягає в таких постулатах:

- відсутність адміністративного контролю, що обмежує свободу педагогічної творчості;

- активність учнів у навчальному процесі, орієнтація на інтереси та досвід учнів, створення навчального середовища, яке б перетворило навчання на яскравий елемент життя дитини;

- практична спрямованість освітньої діяльності, взаємозв'язок особистого розвитку дитини з її практичним досвідом;

- відмова від орієнтації освітнього процесу на середнього школяра і обов'язкове врахування інтересів кожної дитини;

- виховання вільної незалежної особистості;

- забезпечення свободи і права дитини в усіх проявах їі діяльності, урахування її вікових та індивідуальних особливостей, забезпечення морально-психологічного комфорту дитини;

- впровадження шкільного самоврядування, яке під свободою і самостійністю дитини передбачає виховання гуманістичних та демократичних ідей і світогляду, необхідних сучасному суспільству [9].

Одним із важливих пріоритетів організації освітнього процесу в НУШ $є$ завдання формування в учнів системи загальнолюдських цінностей. У Концептуальних засадах реформування середньої школи запропоновано об'єднати такі поняття, як «освіта», «освітній процес» у єдине ціле, що охоплює навчання, виховання і розвиток, тобто виховний процес розглядається як невід'ємна і наскрізна складова освітнього процесу в цілому. В основі системи загальнолюдських цінностей у НУШ виокремлено морально-етичні та соціально-політичні. Зокрема акцентовано увагу на формуванні в учнів таких морально-етичних цінностях, як-то: гідність, чесність, справедливість, турбота, повага до життя, повага до себе та інших людей. Водночас освітній процес повинен бути спрямований на формування в школярів соціально-політичних цінностей, а саме: свободи, демократії, культурного різноманіття, поваги до рідної мови і культури, патріотизму, шанобливого ставлення до довкілля, поваги до закону, солідарності, відповідальності. 
Як зазначається в «Пораднику для вчителя НУШ», виховання в учнів відповідальності за себе і за добробут країни має перебувати в центрі загальної парадигми освіти.

Відповідно до цього в дидактико-методичному забезпеченні освітнього процесу в початковій освіті повинні враховуватися такі організаційні орієнтири:

- виховання не зводиться лише до окремих виховних занять;

- увесь колектив школи залучається до створення виховного середовища;

- учитель $є$ взірцем людини вихованої, який своїм прикладом надихає і зацікавлює дитину;

- у плануванні діяльності необхідно враховувати індивідуальні нахили, здібності кожної дитини і створювати належні умови для їх реалізації;

- співробітництво з позашкільними закладами освіти;

- активне залучення до співпраці психологів і соціальних педагогів;

- налагодження постійного діалогу з батьківською спільнотою [10].

Оновлена структура освітнього процесу в початковій школі, зокрема іiї розподіл на два цикли навчання: перший - адаптаційно-ігровий (1-2 класи) і другий - основний (34 класи), є одним із шляхів реалізації особистісно орієнтованої моделі навчання. Передусім такий розподіл вмотивований віковими особливостями психофізіологічного, пізнавального розвитку та потребами дітей і спрямований на подолання розбіжностей у досягненнях, що обумовлено готовністю школярів до здобуття освіти. Відповідно кожен цикл має свою мету й особливості методичних прийомів і методів.
Так, метою першого циклу є адаптація дитини до шкільного життя, до нового для неї середовища. У Державному стандарті початкової освіти задекларовано, що організація освітнього процесу на цьому етапі повинна здійснюватися із застосуванням діяльнісного підходу на інтегрованій основі та з переважанням ігрових методів [11]. У Концепції НУШ наголошено, що адаптуватися до шкільного життя учневі допоможуть такі підходи до організації освітнього процесу:

- зміст і обсяг навчальних завдань формується з урахуванням індивідуальних особливостей учнів;

- інтеграція навчального матеріалу може здійснюватися як у змісті споріднених предметів, так і шляхом введення до складу окремих предметів у вигляді модулів;

- обмеження в обсязі домашніх завдань;

- реалізація діяльнісного підходу через застосування ігрових методів навчання в класі й поза його межами;

- надання автономії вчителю, зокрема свободи у виборі чи створенні авторських навчальних програм у межах Державного стандарту початкової освіти;

- запровадження описового формувального оцінювання, метою якого серед іншого $€$ підтримка в учневі впевненості й мотивації до навчання [1].

Метою другого циклу початкової освіти $є$ організація освітнього процесу з концентрацією педагогічної уваги на формуванні в учнів відповідальності та самостійності, а також підготовка школярів до успішного навчання на рівні базової середньої освіти. Відповідно до Державного стандарту початкової освіти організація освітнього процесу повинна здійснюватися 
також із застосуванням діяльнісного підходу, але на інтегровано-предметній основі [11]. 3 огляду на це суттєвими ознаками організації освітнього процесу визначено такі:

- використання в освітньому процесі методів, які привчають учня здійснювати самостійний вибір, пов'язувати вивчене з практичним життям і водночас враховують його індивідуальність;

- запровадження предметного навчання;

- запровадження бального оцінювання результатів навчання з частини предметів [10].

Важливого значення в контексті Нової української школи набуває організація освітнього середовища, яке передусім повинно бути творчим, забезпечувати використання різних форм роботи, сприяти розвитку в учнів стійкого пізнавального інтересу, формувати потреби в знаннях і мотивувати до навчання [12]. Зміни в організації освітнього середовища зумовлені тим, що в освітньому процесі збільшилася частка групової, проєктної і дослідницької діяльності, а це вимагає урізноманітнити варіанти упорядкування освітнього простору. Зокрема організація освітнього середовища в класі повинна бути спрямована на реалізацію права дитини на вибір місця навчання, його темпу та водночас надавати вчителю можливості швидко реагувати на потреби здобувачів освіти [13].

Відповідно до Методичних рекомендацій щодо організації освітнього простору Нової української школи, затверджених наказом МОН № 283 від 23.03.2018 р., зміни в просторовопредметному оточенні, програмах i засобах навчання покликані сприяти вільному розвитку творчої особис- тості дитини. У рекомендаціях наголошено на створенні (організації) навчальних центрів (осередків), які відображатимуть освітні потреби й інтереси дітей, як-то:

- осередок навчально-пізнавальної діяльності;

- змінні тематичні осередки;

- осередок для гри,

- осередок художньо-творчої діяльності;

- куточок живої природи;

- осередок відпочинку;

- дитяча класна бібліотека;

- осередок вчителя [14].

Варто зауважити, що створення освітнього середовища - це спільна діяльність усіх учасників освітнього процесу. Роль учителя полягає у створенні основи цього середовища, а його формування відбувається за участі як дітей, так і їхніх батьків.

Окремо в методичних рекомендаціях наголошується на вимогах до шкільного обладнання, яке повинно відповідати зокрема таким вимогам, як ергономічність, безпечність, міцність та естетичність. Також рекомендується використовувати новітні робочі місця, які є мобільними і за потреби можуть бути трансформовані, наприклад для роботи в групах [14].

У підсумку освітнє середовище в Новій українській школі - це комплексне поняття, яке об'єднує два виміри: соціальний і просторово-предметний, і спрямований на формування особистості дитини та її розвиток.

Освітнє середовище - сукупність об'єктивних зовнішніх умов, факторів, соціальних об'єктів, необхідних для успішного функціонування освіти. Це система впливів і умов формування особистості, а також можливостей для іï розвитку, які містяться в 
соціальному і просторово-предметному оточенні.

Важливим фактором успішного упровадження освітньої реформи Нової української школи, безперечно, $\epsilon$ сприйняття інновацій безпосередніми її учасниками - учителями початкової школи. При цьому акцентується увага не тільки на ставленні педагогів до тих чи інших новацій, а й готовність утілювати їх у своїй щоденній практичній діяльності, володіючи для цього необхідними знаннями та навичками. Починаючи зі старту реформи, щорічно впродовж трьох років ДНУ «Інститут освітньої аналітики» у співпраці з Міністерством освіти і науки України проводить моніторингове дослідження серед учителів початкової ланки освіти щодо готовності педагогічних працівників до реалізації Концепції НУШ. 3-поміж різних аспектів дослідження розглядалося зокрема ставлення учителів до основних принципів НУШ щодо організації діяльності в закладах освіти.
Порівняльний аналіз результатів досліджень трьох років (2018-2020рр.) за показником «повністю схвалюю» дає підстави говорити про позитивну динаміку в ставленні до ключових принципів НУШ, як-то: переходу на компетентнісне навчання, педагогіки партнерства, нових стандартів початкової середньої освіти (це питання вивчалося лише в 2018 і 2020 рр.), автономії школи - серед головних провайдерів реформи. Найбільшою підтримкою користується педагогіка партнерства, також у ставленні до неї зафіксовано найбільше зростання беззастережного схвалення педагогів: на $9 \%$ і 13 \% у 2020 р. в порівнянні з результатами 2018 р. і 2019 р. відповідно. Найменша частка вчителів «повністю схвалює» нові стандарти початкової середньої освіти, хоча при зіставленні результатів двох циклів дослідження (2018 і 2020 рр.) теж зафіксовано позитивну динаміку й зростання підтримки майже на 4 \% (рис. 1).

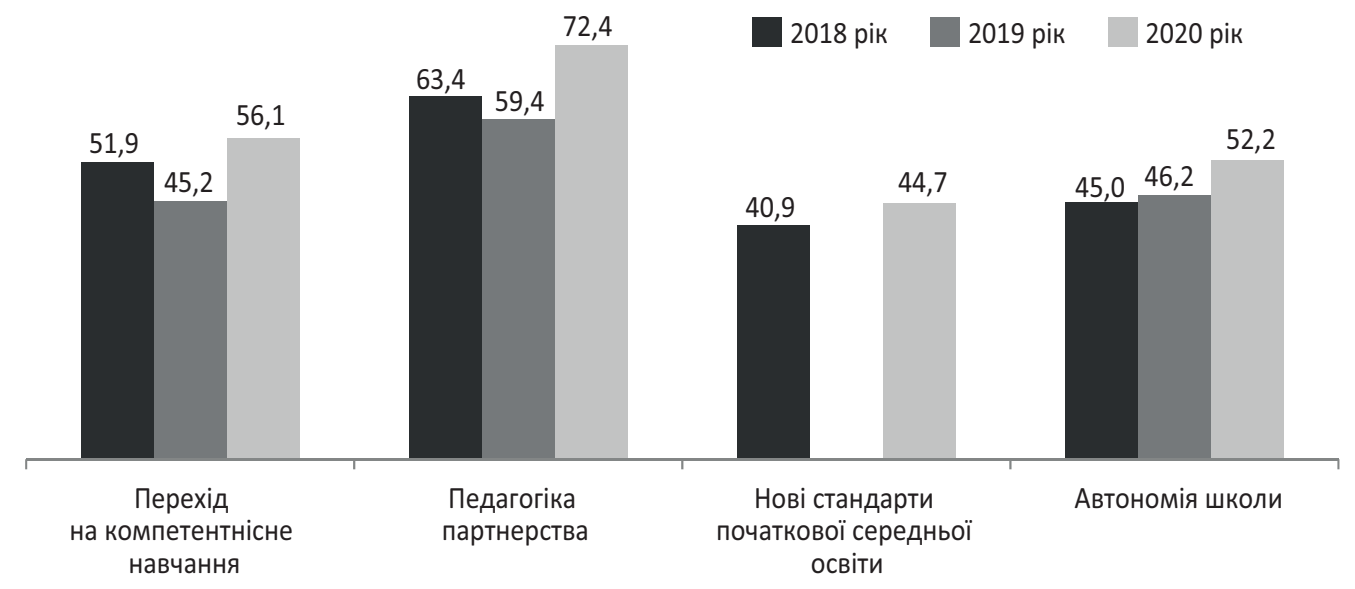

Рис. 1. Розподіл учителів за ставленням до принципів НУШ щодо організації діяльності в закладах освіти, \%

Побудовано за результатами опитування вчителів, проведеного в межах «Дослідження щодо готовності педагогічних працівників до реалізації Концепції Нової української школи» (2018-2020 pр.) [15-17]. 
Порівняльний аналіз трьох циклів (2018-2020 рр.) згаданого моніторингового дослідження щодо готовності педагогів початкової освіти до провадження освітньої діяльності на основі принципів НУШ, зокрема відповідно до нового Державного стандарту початкової освіти, на основі компетентнісного підходу та щодо реалізації інтегрованого навчання, за сумарним показником «повністю підготовлений і швидше підготовлений» дозволяє констатувати також позитивну динаміку. Найбільший приріст (понад $10 \%$ простежується щодо готовності вчителів викладати, реалізуючи принцип інтегрованого навчання, за результатами дослідження 2020 р. у порівнянні з першим і другим циклами 2018 р. і 2019 р. Загалом на третій рік упровадження освітньої реформи майже 100 \% педагогів почуваються підготовленими до викладання в межах НУШ (рис. 2).

Водночас більшість (від 88,9 \% до 98,2 \%) учителів - респондентів двох перших циклів (2018 і 2019 рр.) дослідження рівня готовності педагогічних працівників до реалізації Концепції НУШ - констатували практичну реалізацію підходів щодо організації освітнього простору Нової української школи, зокрема щодо наявності в класах освітніх осередків, а саме: навчально-пізнавальної діяльності, художньо-творчої діяльності, ігрової діяльності, змінні тематичні осередки тощо [15; 16]. Варто зауважити, що у 2020 р. це питання в межах дослідження з об'єктивних причин не розглядалося.

Таким чином, аналіз основних підходів, які використовуються в початковій освіті при запровадженні концепції Нової української школи, здійснено крізь призму поняття «освітнього процесу», його ключової ролі при формуванні компетентностей учнів. Зокрема важливим орієнтиром в освітньому процесі $€$ дитиноцентризм як невід'ємна частина особистісно орієнтованої моделі навчання дітей,

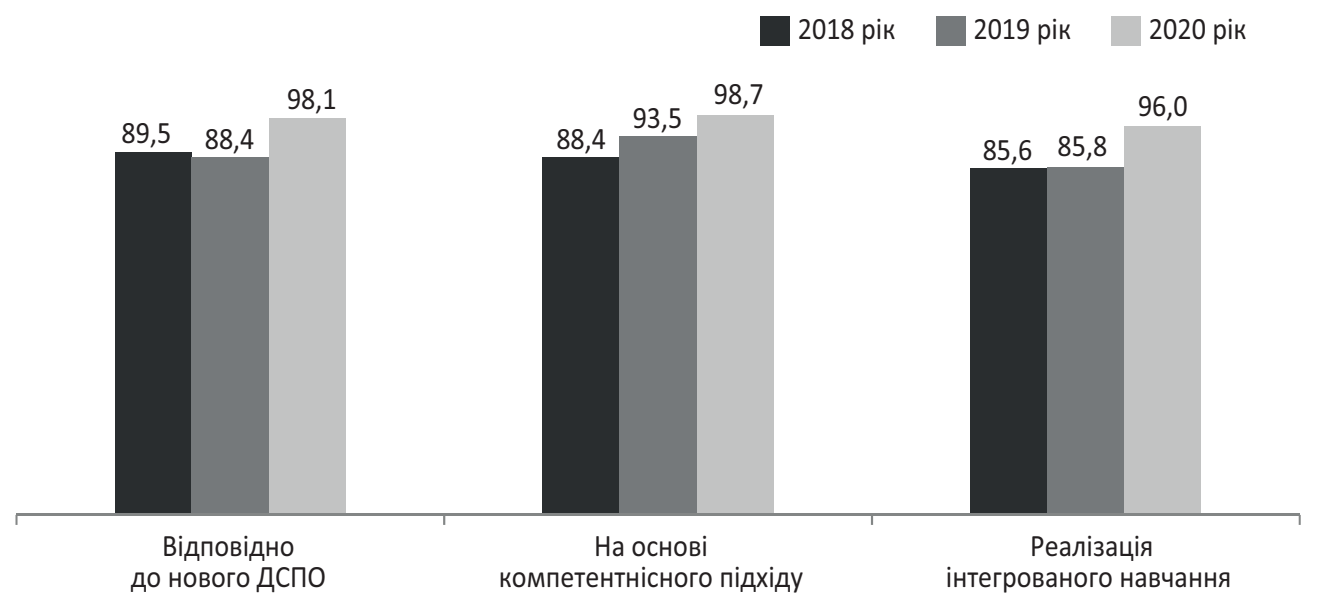

Рис. 2. Розподіл учителів за оцінкою їхньої готовності викладати в межах реформи НУШ, \%

Побудовано за результатами опитування вчителів, проведеного в межах «Дослідження щодо готовності педагогічних працівників до реалізації Концепції Нової української школи» (2018-2020рр.) [15-17]. 
що спрямована на персоналізацію освітнього процесу, свободу вибору власної освітньої траєкторії, урахування цінностей та інтересів дитини для формування в неї основ життєвої компетентності. Структура освітнього процесу в початковій школі за новою концепцією передбачає розподіл на два цикли навчання: адаптаційно-ігровий і основний, що є одним зі шляхів реалізації особистісно орієнтованої моделі навчання. Такий розподіл враховує вікові, психофізіологічні та пізнавальні особливості дітей і спрямований на подолання розбіжностей у досягненнях, що обумовлено готовністю учнів до здобуття освіти. Основним завданням освітнього процесу в НУШ $є$ формування в учнів системи загальнолюдських цінностей, в основі яких виокремлено морально-етичні (гідність, чесність, справедливість та ін.) та соціально-політичні (повага до рідної мови і культури, свободи, демократії, культурного різноманіття тощо). Створення освітнього середовища $є$ невід'ємною частиною ефективного впровадження реформи. Зміни в ньому є важливими з огляду на збільшення в освітньому процесі групової, проєктної і дослідницької діяльності. Освітнє середовище в класі має бути спрямоване на забезпечення принципу особистісно орієнтованої моделі навчання.

Упровадження освітньої реформи Нової української школи схвально оцінюють безпосередні їі провайдери - учителі початкової ланки загаль- ної середньої освіти. Це підтверджено зокрема результатами моніторингового дослідження, що проводилося ДНУ «Інститут освітньої аналітики» спільно з Міністерством освіти і науки України упродовж 2018-2020рр., щодо готовності педагогічних працівників до реалізації концепції НУШ. Так, зафіксовано позитивну динаміку щодо абсолютної підтримки (показник «повністю схвалюю») серед учителів педагогіки партнерства (у середньому на 11 \%), запровадження компетентнісного підходу (у середньому на 7,5 \%), автономії школи (у середньому на 6,6 \%), нових стандартів початкової освіти (майже на 4 \%). Водночас підвищилася впевненість учителів щодо власного рівня підготовленості до викладання відповідно до нового Державного стандарту початкової освіти (у середньому на 9,2 \%), на основі компетентнісного підходу (у середньому на 7,8 \%), інтеграції навчальних предметів (у середньому на 10,3 \%). Також у більшості класів, за результатами опитування вчителів у 2018 і 2019 рр., створено освітні осередки для реалізації нових підходів до навчання учнів початкової школи відповідно до Концепції НУШ. Основними перспективними напрямами подальшої аналітичної роботи $\epsilon$ проведення моніторингових досліджень запровадження концепції Нової української школи для визначення сильних і слабких сторін реформи, вивчення ставлення до неї всіх учасників освітнього процесу.

\section{Список використаних джерел}

1. Про освіту : Закон України від 05.09.2017 № 2145-VIII. URL: https://zakon.rada. gov.ua/laws/show/2145-19\#Text (дата звернення: 17.02.2021). 
2. Про повну загальну середню освіту : Закон України від 16.01.2020 № 463-IX. URL: https://zakon.rada.gov.ua/laws/show/463-20\#Tехt (дата звернення: 17.02.2021).

3. Про затвердження Методичних рекомендацій щодо організації освітнього простору Нової української школи : наказ Міністерства освіти і науки України від 23.03.2018 № 283. URL: https://mon.gov.ua/storage/app/media/zagalna\%20serednya/ nop/3metodichni-rekomendatsii.pdf.

4. Державний стандарт початкової освіти : затв. постановою Кабінету Міністрів України від 21.02.2018 № 87. URL: https://zakon.rada.gov.ua/laws/show/87-2018$\%$ D0\%BF\#top.

5. Бібік Н. М. Нова українська школа: порадник для вчителя. Київ : Плеяди, 2017. 206 c.

6. Водолазька Т. В. Освітнє середовище як «третій учитель». Точка зору. 2018. № 4 (181). C. 10-12.

7. Кремень В. Г. Філософія людиноцентризму в стратегіях освітнього простору. Київ : Пед. думка, 2008. 424 с.

8. Ляшенко O. I. Пріоритети розвитку української школи в умовах реформування освіти. Збірник наукових праць Кам'янець-Подільського національного університету ім. Івана Огієнка. Сер. : педагогічна. 2016. Вип. 22. С. 39-42. URL: http://nbuv.gov.ua/ UJRN/znpkp_ped_2016_22_13.

9. Набок М. В. Дитиноцентризм - стрижневий вектор розвитку загальної середньої освіти України початку 21-го століття. Духовність особистості: методологія, теорія і практика. 2017. Вип. 3 (78). С. 159-172.

10. Онищук Л. А. Нова українська школа: реалії та перспективи. Український педагогічний журнал. 2018. № 1. URL: http://nbuv.gov.ua/UJRN/ukrpj_2018_1_8.

11. Онопрієнко O. В. Нова українська школа: актуалітети модернізації початкової загальної освіти. Проблеми сучасного підручника. 2017. Вип. 19. С. 244-252. URL: http:// nbuv.gov.ua/UJRN/psp_2017_19_29.

12. Савченко О. А. Початкова освіта в контексті ідей Нової української школи і учнів. Директор школи, ліщею, гімназії. 2018. T. 19. № 2. C. 4-10. URL: https://director-ua.info/ index.php/dslg/article/view/51.

13. Carlson P. A. Advanced Educational Technologies - Promise and Puzzlement (RoseHulman Institute of Technology). Journal of Universal Computer Science. 2018. Vol. 4. Issue 3. P. 210-215.

14. Дослідження умов реформування загальної середньої освіти на початку 20182019 н. p. в контексті освітньої діяльності вчителів 1 класів : аналіт. звіт. URL: https:// iea.gov.ua/wp-content/uploads/2020/06/Doslidzhennya-umov-reformuvannya-zagalnoyiserednoyi-osviti-na-pochatku-2018-2019-n.-r.-v-konteksti-osvitnoyi-diyalnosti-vchiteliv-1klasiv_2018.pdf.

15. Дослідження щодо готовності педагогічних працівників до реалізації Концепції Нової української школи : аналіт. звіт. URL: https://iea.gov.ua/wp-content/ uploads/2020/06/Doslidzhennya-shhodo-gotovnosti-pedagogichnih-pratsivnikiv-dorealizatsiyi-Kontseptsiyi-Novoyi-ukrayinskoyi-shkoli_2019.pdf.

16. Дослідження щодо готовності педагогічних працівників до реалізації Концепції Нової української школи : аналіт. звіт. URL: https://iea.gov.ua/wp-content/ uploads/2020/10/13.-Teachers_Report_2020.pdf.

17. Нова українська школа : концептуальні засади реформування середньої школи. URL: https://mon.gov.ua/storage/app/media/zagalna\%20serednya/nova-ukrainskashkola-compressed.pdf. 


\title{
Valentyna Tkachenko
}

SSI «Institute of Educational Analytics», Kyiv, Ukraine, v.tkachenko@iea.gov.ua

ORCID ID: https://orcid.org/0000-0002-3389-9935

\section{Tetiana Dron}

SSI «Institute of Educational Analytics», Kyiv, Ukraine, t.dron@ iea.gov.ua

ORCID ID: https://orcid.org/0000-0003-1374-5610

\section{INNOVATIVE APPROACHES TO THE EDUCATIONAL PROCESS ORGANIZATION IN PRIMARY SCHOOL FOR THE NUS}

\begin{abstract}
This article considers innovative approaches to the organization of the educational process in primary school within the implementation of the concept of the New Ukrainian School, their role in the development of the child as a person, the importance of transforming the educational process during the reform. The purpose of this material is to review innovative approaches to the organization of the educational process in primary school during the concept implementation in the «New Ukrainian School» (hereinafter - the NUS) with emphasis on the personality-oriented model of education based on the child-centered principles; formation of universal values; structure of educational process and organization of the educational environment. Methods of scientific analysis and methods of texts research were applied to consider the features of the educational process in the conditions of educational system transformation. Among the key aspects of primary education, the ideology of a childcentered approach is considered as the basis of a personality-oriented model of education, within which the organization of the educational process should take into account the rights of each child, his abilities, needs and interests. The material also analyzed the updated structure of the educational process in primary school, in particular its division into two cycles of learning such as adaptive-game and basic, which is one of the ways to implement a personality-oriented model of learning. This distribution takes into account the age features of psychophysiological, cognitive development and needs of students. In the context of the New Ukrainian School, it is very important to create an educational environment, which should be creative and ensure the use of various forms of work, promote the development of students' sustainable cognitive interest, its development should be coordinated efforts of all participants in the educational process. The results of research on key aspects of the NUS reform are also presented.
\end{abstract}

Keywords: child-centered approach, innovations, competencies, concept, New Ukrainian School, educational process, personality, approaches, primary education, values.

\section{References}

1. Verkhovna Rada of Ukraine. (2017). About education (Act No. 2145-VIII, September 5). Retrieved from https://zakon.rada.gov.ua/laws/show/2145-19\#Text [in Ukrainian].

2. Verkhovna Rada of Ukraine. (2020). On general secondary education (Act No. 463-IX, January 16). Retrieved from https://zakon.rada.gov.ua/laws/show/463-20 [in Ukrainian].

3. Ministry of Education and Science of Ukraine. (2018). About the statement of Methodical recommendations concerning the organization of educational space of New Ukrainian school (Order No. 283, March 23). Retrieved from https://mon.gov.ua/storage/app/media/ zagalna\%20serednya/nop/3metodichni-rekomendatsii.pdf [in Ukrainian].

4. Cabinet of Ministers of Ukraine. (2018). About the statement of the State standard of primary education (Decree No. 87, February 21). Retrieved from https://zakon.rada.gov.ua/ laws/show/87-2018-\%D0\%BF\#top [in Ukrainian]. 
5. Bibik, N. M. (2017). New Ukrainian school: a guide for teachers. Kyiv: Pleyadi, 206 [in Ukrainian].

6. Vodolazka, T. V. (2018). Educational environment as a "third teacher". Tochka zoru, 4(181), 10-12 [in Ukrainian].

7. Kremen, V. H. (2008). Philosophy of anthropocentrism in the strategies of educational space. Kyiv: Pedagogichna dumka, 424 [in Ukrainian].

8. Liashenko, O. I. (2016). Priorities of Ukrainian school development in the conditions of education reform. Collection of scientific papers of the Kamyanets-Podilsky National University named after Ivan Ogienko. Series: pedagogical, 22, 39-42. Retrieved from http:// nbuv.gov.ua/UJRN/znpkp_ped_2016_22_13 [in Ukrainian].

9. Nabok, M. V. (2017). Child-centeredness is the core vector of the development of general secondary education in Ukraine at the beginning of the 21st century. Duhovnist' osobistosti: metodologiya, teoriya i praktika, 3(78), 159-172 [in Ukrainian].

10. Onyshchuk, L. A. (2018). New Ukrainian school: realities and prospects. Ukrainian pedagogical journal, 1. Retrieved from http://nbuv.gov.ua/UJRN/ukrpj_2018_1_8 [in Ukrainian].

11. Onopriienko, O. V. (2017). New Ukrainian school: actualities of modernization of primary general education. Problemi suchasnogo pidruchnika, 19, 244-252. Retrieved from http://nbuv.gov.ua/UJRN/psp_2017_19_29 [in Ukrainian].

12. Savchenko, O. A. (2018). Primary education in the context of the ideas of the New Ukrainian School and students. Direktor shkoli, liceyu, gimnaziï, 19(2), 4-10. Retrieved from https://director-ua.info/index.php/dslg/article/view/51 [in Ukrainian].

13. Carlson, P. A. (2018). Advanced Educational Technologies - Promise and Puzzlement (Rose-Hulman Institute of Technology). Journal of Universal Computer Science, 4(3), 210-215.

14. SSI "Institute of Educational Analytics". (2018). Study of the conditions for reforming general secondary education in early 2018-2019. in the context of the educational activities of teachers of 1st grade. Retrieved from https://iea.gov.ua/wp-content/uploads/2020/06/ Doslidzhennya-umov-reformuvannya-zagalnoyi-serednoyi-osviti-na-pochatku-2018-2019n.-r.-v-konteksti-osvitnoyi-diyalnosti-vchiteliv-1-klasiv_2018.pdf [in Ukrainian].

15. SSI "Institute of Educational Analytics". (2019). Research on the readiness of teachers to implement the Concept of the New Ukrainian School. Retrieved from https://iea.gov.ua/wpcontent/uploads/2020/06/Doslidzhennya-shhodo-gotovnosti-pedagogichnih-pratsivnikivdo-realizatsiyi-Kontseptsiyi-Novoyi-ukrayinskoyi-shkoli_2019.pdf [in Ukrainian].

16. SSI "Institute of Educational Analytics". (2020). Research on the readiness of teachers to implement the Concept of the New Ukrainian School. Retrieved from https://iea.gov.ua/ wp-content/uploads/2020/10/13.-Teachers_Report_2020.pdf [in Ukrainian].

17. Ministry of Education and Science of Ukraine. (2016). The new Ukrainian school: conceptual principles of secondary school reform. Retrieved from https://mon.gov.ua/storage/ app/media/zagalna\%20serednya/nova-ukrainska-shkola-compressed.pdf [in Ukrainian]. 